\title{
PENGARUH VARIASI DOSIS LARUTAN DAUN SERAI (Andropogon nardus L.) TERHADAP MORTALITAS LARVA NYAMUK Aedes sp SEBAGAI SUMBER BELAJAR BIOLOGI
}

\author{
Dewi Astuti ${ }^{1}$ \\ Handoko Santoso ${ }^{2}$ \\ ${ }^{1,2}$ Pendidikan Biologi FKIP Universitas Muhammadiyah Metro \\ E-mail: deewiiastutii@yahoo.co.id
}

\begin{abstract}
This research was to now there was any influence of variant dose of lemongrass solvent toward the mortality of mosquitoes larvae Aedes sp,to know the solvent dose of lemongrass was the most effective to decrease mosquitoes larvae Aedes sp, to find out the potential results of the research as the learning source of biology at the eleventh grade of SMP in odd semester. This research used Completely Randomized Design (CRD or RAL) as the research design. Dependent Variable in this research was the mortality of Aedes sp larvae and the independent variable was the variation of lemongrass solvent $(15 \%, 20 \%, 25 \%$, $30 \%, 35 \%)$. This research was done with giving the variation lemongrass solvent dose in a plastic glass. At that time the researcher filled ten larvae into the glass in every treatment with 5 replication and then counted how many larvae which have dead in 24 hours. The interval of the research was 2 hours. The data analysis was a non-parametric test of Wallis- Kruskal one-way. Based on the result of the observation during 24 hours toward the average mortality of Aedes sp larvae from the lowest up to the highest are the treatment 15\% become 38, the treatment $20 \%$ into $52 \%$, the treatment $25 \%$ turn out $66 \%$, the treatment $30 \%$ become $86 \%$ and the last the treatment $35 \%$ increased in $98 \%$. Based on analysis test result of Wallis Kruskal, the researcher got the coefficient $H=x 2$ arithmetic 33,79\% > 22 table 19,67 on a 0,05. It means that there was an influence lemongrass solvent variation toward the mortality of Aedes sp larvae. The content of lemongrass solvent dose $35 \%$ was the best and it has the biggest influence to decrease the mortality of Aedes sp larvae. The result of this research can be used as the biology learning source at the eighth grade of junior high school in odd semester then it is suitable for the sub-material of metamorphosis in animals.
\end{abstract}

Kata Kunci: tumbuhan pewarna alami, Work sheet Students

Demam Berdarah Dengue (DBD) adalah salah satu jenis penyakit yang akut (mendadak) disebabkan oleh virus dengue. Nyamuk Aedes sp. merupakan vektor utama demam berdarah dengue dan cikungunya. Demam berdarah dengue dan cikungunya merupakan salah satu masalah kesehatan lingkungan yang saat ini semakin luas daerah penyebarannya dan penderitanya cenderung meningkat.

Walaupun kasus DBD dan cikungunya mengalami penurunan tetapi dari tahun ke tahun tetap ada penderita yang mengalami kematian. hal ini dapat dilihat pada Tabel 1.

Tabel 1. Kasus Demam Berdarah Dengue (DBD) dan Cikungunya di Kota Metro

\begin{tabular}{|c|c|c|c|}
\hline \multirow[t]{2}{*}{ Tahun } & \multicolumn{2}{|c|}{$\begin{array}{c}\text { Total kasus Demam } \\
\text { Berdarah Den gue (DBD) } \\
\text { dan Cikunguny a }\end{array}$} & \multirow[t]{2}{*}{$\begin{array}{l}\text { Jumlah } \\
\text { penduduk }\end{array}$} \\
\hline & Penderita & Meninggal & \\
\hline 2008 & 619 & 6 & 134.682 \\
\hline 2009 & 118 & 4 & 137.392 \\
\hline 2010 & 115 & 2 & 138.457 \\
\hline 2011 & 26 & - & 148.163 \\
\hline 2012 & 390 & 5 & 156.293 \\
\hline
\end{tabular}

Sumber:Dinas Kesehatan Kota Metro 
Berbagai upaya mengusir dan mencegah gigitan nyamuk telah dilakukan oleh pemerintah dan masyarakat kota Metro yaitu pengendalian lingkungan yang digalakkan dengan menutup tempattempat penyimpanan air bersih, mengubur berang-barang bekas, pengasapan (fogging), dan penggunakan bubuk abate pada stadium pendewasaan. Selain itu juga dilakukan pengendalian habitat nyamuk menggunakan bahan kimia atau dengan menggunakan agen hayati, serta perlindungan terhadap individu menggunakan zat penolak atau repelen. Sedangkan repelen yang selama ini dikenal terbuat dari bahan kimia sintetis sehingga relatif dapat menimbulkan gangguan kulit yang peka.

Pemberantasan nyamuk salah satunya adalah dengan cara memutuskan rantai penularannya yaitu dengan menggunakan bahan kimia atau insektisida sintetis seperti obat nyamuk semprot atau obat nyamuk bakar (Adiseputra, 2009:7). Hal ini banyak dipilih oleh masyarakat kota Metro karena praktis dan mudah. Namun, disamping adanya dampak positif yang dihasilkan yaitu dapat membunuh nyamuk penular secara cepat, ada pula dampak negatif yang dihasilkan oleh bahan kimianya yaitu mampu mempengaruhi kesehatan pada manusia, hewan ternak, polusi lingkungan, dan hama (nyamuk) menjadi resisten.

Upaya mengurangi
penggunaan insektisida kimia
sintetik sangatlah bijak. Bila
mengoptimalkan penggunaan
tumbuhan yang mempunyai
kemampuan sebagai insektisida
nabati terutama bagi nyamuk Aedes
$\begin{aligned} & \text { sp. Insektisida nabati merupakan } \\ & \text { bahan alami, bersifat mudah terurai }\end{aligned}$

di alam (biodegradable) sehingga tidak mencemari lingkungan dan relatif aman bagi manusia maupun ternak karena residunya mudah hilang (Naria, 2005:29). Insektisida nabati dapat dibuat secara sederhana dan kemampuan yang terbatas. Bila senyawa atau ekstrak ini digunakan di alam, maka tidak mengganggu organisme lain yang bukan sasaran.

Serai (Andropogon nardus L.) merupakan salah satu tanaman asli Indonesia yang berpotensi sebagai larvasida. Serai mengandung sitronellal, geraniol, dan minyak atsiri, yang diduga senyawa-senyawa ini dapat berfungsi sebagai insektisida. Sitronella dan geraniol merupakan bahan aktif yang tidak disukai dan sangat dihindari serangga, termasuk nyamuk sehingga penggunaan bahan-bahan ini sangat bermanfaat sebagai pengusir nyamuk. Sitronella dan geraniol merupakan bahan aktif yang tidak disukai dan sangat dihindari serangga, termasuk nyamuk sehingga penggunaan bahan-bahan ini sangat bermanfaat sebagai pengusir nyamuk (Kardinan, 2003). Menurut cara kerjanya racun ini seperti racun kontak yang dapat memberikan kematian karena kehilangan cairan secara terus menerus sehingga tubuh nyamuk akan kekurangan cairan, sehingga menyebabkan kematian (Arswendiyumna, 2011:02).

Tanaman yang diambil adalah tanaman serai yang sudah bisa diproduksi atau yang sudah tua yang memilik warna daun hijau tua keunguan, karena kandungan senyawa sitronella lebih banyak daripada daun yang masih muda. Dalam pemberantasan larva nyamuk Aedes $s p$ ini dipilih larvanya, karena pada fase perkembangannya, jika larva tidak segera diberantas secepat mungkin maka akan tumbuh menjadi 
nyamuk dewasa, tentunya akan semakin sulit untuk diberantas.

Berdasarkan penelitian ini, proses dan produk penelitian yang dihasilkan diharapkan dapat dipergunakan sebagai bahan untuk membuat sumber belajar berupa lembar penuntun praktikum siswa SMP kelas VIII semester ganjil pada Standar Kompetensi (SK) Memahami Pertumbuhan dan Perkembangan Mahluk Hidup, dengan Kompetensi Dasar (KD) Menganalisis pentingnya pertumbuhan dan perkembangan pada mahluk hidup, dengan materi sub pokok metamorfosis pada hewan. Karena dalam penelitian ini berhubungan dengan tahap pengkolonian larva nyamuk dan cara pengendalian Aedes sp secara terpadu menggunakan insektisida nabati. Dengan siswa melakukan pengamatan terhadap perkembangan nyamuk melalui kegiatan praktikum maka dapat memberikan pengetahuan siswa untuk mengetahui proses sampai menjadi nyamuk dewasa dan menguasai konsep yang sudah diberikan sebelumnya oleh guru, sehingga menimbulkan sikap ilmiah bagi siswa yang melakukan pengamatan maupun percobaan tersebut.

Untuk itu dilakukan penelitian ini yang bertujuan (1) untuk mengetahui adanya pengaruh variasi dosis larutan daun serai terhadap mortalitas larva nyamuk Aedes sp, (2) untuk menentukan dosis larutan daun serai yang paling efektif terhadap mortalitas larva nyamuk Aedes sp, dan (3) untuk mengetahui hasil penelitian berpotensi sebagai sumber biologi SMP kelas VIII semester ganjil.

\section{METODE}

Penelitian ini menggunakan metode eksperimen, desain yang digunakan adalah Rancangan Acak Lengkap (RAL), yaitu penelitian dilakukan lima macam perlakuan, dan satu kontrol, untuk masing-masing dilakukan lima kali ulangan (Hanafiah, 2011).

Alat dan bahan yang digunakan dalam penelitian ini adalah kandang nyamuk, gelas plastik, gelas ukur $100 \mathrm{ml}$, gelas kimia $500 \mathrm{ml}$, jarum ose, label, seperangkat alat untuk membuat larutan daun serai meliputi lumpang, timbangan, pisau, gelas ukur $100 \mathrm{ml}$, timbangan, dan baskom. Serta bahan yang digunakan adalah larva nyamuk Aedes sp, air aquades 2 liter, daun serai $2 \mathrm{~kg}$, pakan ikan, larutan gula, dan marmut yang masih hidup.

Dalam pelaksanaan penelitian, dilakukan tiga tahapan peaksanaan yaitu; pertama membuat koloni larva nyamuk Aedes sp, kedua membuat insektisida nabati dari daun serai yang sudah tua, ketiga melakukan eksperimen uji insektisida nabati larutan daun serai pada larva nyamuk Aedes sp.

Tahapan pertama adalah membuat koloni larva. Adapun langkah-langkahnya mengadaptasi dari Ulfah (2009:39) yaitu mengumpulkan larva nyamuk Aedes $s p$ dari berbagai tempat yaitu bak mandi, ban bekas, botol gelas, dan drum bekas, memasukkan larva yang sudah terkumpul ke dalam baskom hitam dan gelas plastik yang sudah berisi air sumur serta diberi pakan ikan, kemudian apabila terbentuk pupa, langsung dimasukkan ke dalam kandang yang sudah dibuat berukuran 1 meter x 1 meter, setelah nyamuk dewasa diberi makan larutan gula, menunggu sampai terjadi perkawinan antara nyamuk betina dan nyamuk jantan, memasukkan marmut yang masih hidup ke dalam kandang sebagai tempat 
perkembangan telur yang dihasilkan nyamuk betina dari perkawinannya, memasukkan kertas saring atau kertas tis sue di tepi baskom dan gelas plastik sebagai tempat peletakan telur, menetaskan telur sampai menjadi larva selama 6 hari, larva siap dijadikan untuk penelitian.

$$
\text { Tahap kedua adalah }
$$

pembuatan insektisida nabati dalam bentuk larutan berbahan dasar daun serai, yaitu dengan cara menyiapkan bahan daun serai yang sudah tua kemudian dikeringanginkan, membersihkan bagian daun serai, memotong kecil-kecil sepanjang \pm 3 $\mathrm{cm}$, menimbang sebanyak 2000 gram, menumbuk daun serai dengan lumpang, kemudian hasil tumbukan ditiriskan ke dalam wadah yang kedap udara, menambahkan aquades sebanyak $2000 \mathrm{ml}$, merendam selama 24 jam, kemudian menyaring dan larutan di masukan ke dalam botol sebanyak $1500 \mathrm{ml}$, larutan daun serai siap digunakan, sesuai dosis yang ditentukan yaitu, 15\%, 20\%, 25\%, $30 \%$, dan $35 \%$, Dosis larutan daun serai siap digunakan untuk eksperimen membasmi larva Aedes $s p$ setelah diencerkan.

Selanjutnya tahap ketiga yaitu pengamatan, dilakukan dengan menghitung larva yang mati pada gelas plastik dengan cara melihat secara kasat mata keadaan mortalitas larva nyamuk Aedes sp. adapun langkah-langkahnya dalam pelaksanaan penelitian yaitu, membuat koloni larva nyamuk Aedes $s p$, membuat insektisida nabati dalam bentuk larutan berbahan dasar daun serai, menyiapkan gelas plastik sebanyak 30 buah, dan mengisi dengan air $10 \mathrm{ml}$ dari tempat larva, kemudian memasukan pada tiap-tiap gelas sebanyak 10 ekor larva nyamuk, memberikan label pada masing-masing gelas plastik untuk masing-masing perlakuan, mengukur $100 \mathrm{ml}$ larutan daun serai untuk setiap dosis sebanyak 5 kali ulangan, menuangkan larutan yang sudah diukur ke dalam gelas plastik kosong yang sudah diberi label untuk perlakuanya, menuangkan tiap dosis larutan kedalam masing-masing gelas plastik berisi larva yang telah diberi label sesuai dengan dosis serta ulanganya masing-masing. misalkan pada perlakuan pertama terdapat 5 kali ulangan, maka larutan dengan dosis $15 \%$ yang sudah diukur sebanyak $100 \mathrm{ml}$ di tuangkan ke dalam gelas plastik yang berisi larva dengan label perlakuan pertama untuk ulangan pertama, untuk masing-masing ulangan pemberian larutan sama yaitu $100 \mathrm{ml}$ larutan daun serai begitu juga untuk dosis yang lainya.

\section{HASIL}

Data hasil pengamatan mortalitas larva Aedes sp selama 24 jam dalam 12 kali pengamatan dengan interval waktu 2 jam.

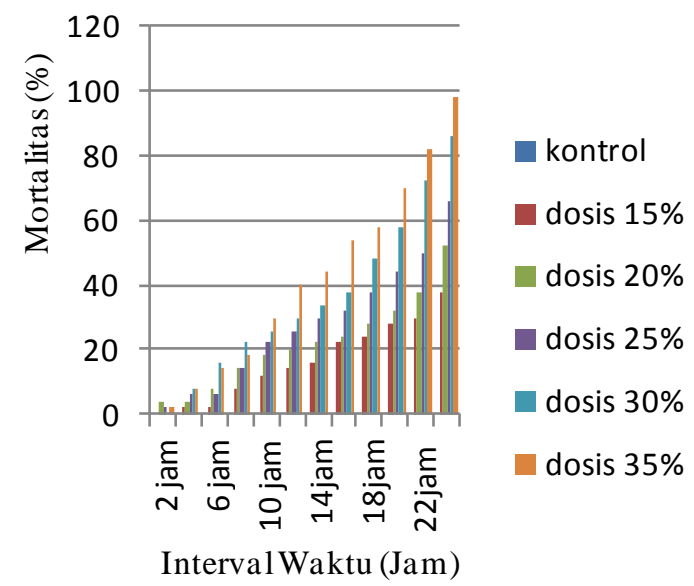

Gambar 1. Diagram Mortalitas Larva Aedes sp Selama 24 Jam dalam $12 \quad$ Kali Pengamatan dengan Interval Waktu 2 Jam. 
Selain itu juga dilakukan perhitungan mortalitas larva Aedes $s p$ selama 24 jam dalam lima perlakuan dan satu kontrol dengan pengulangan sebanyak lima kali selama 24 jam dengan interval 2 jam. Hasil secara lengkap dapat dilihat pada Gambar 3.

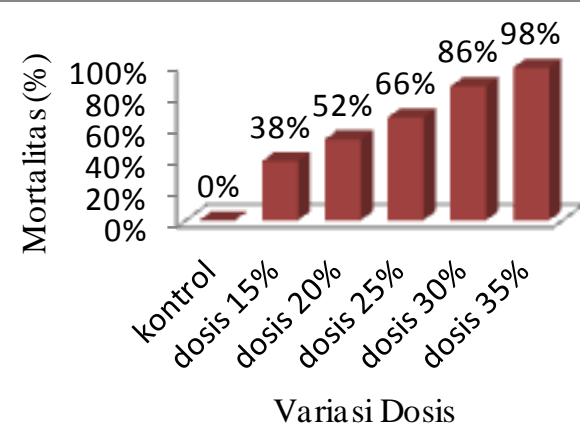

Mortalitas Larva Selama 24 Jam

Gambar 2. Diagram Mortalitas Larva Selama 24 Jam

Berdasarkan Gambar menujukkan bahwa mortalitas selama 24 jam, pada kontrol tidak menunjukan adanya kematian larva Aedes sp sehingga 0\%. Pada dosis larutan daun serai $15 \%$ sebanyak $38 \%$ dari jumlah larva yang mati, kemudian dosis larutan 20\% terdapat $52 \%$ jumla larva yang mati. Selanjutnya dosis larutan 25\% terdapat $66 \%$ larva yang mengalami kematian, dosis larutan $30 \%$ sebanyak $86 \%$ larva mengalami kematian dan pada dosis $35 \%$ terdapat $98 \%$ larva mengalami kematian. Berdasarkan hasil tersebut, dosis larutan daun serai yang paling efektif untuk mortalitas larva Aedes $s p$ adalah dosis 35\%, karena pada dosis ini sudah mampu mengendalikan populasi larva Aedes $s p$ sebesar $98 \%$ dari total larva uji. Suatu larutan dikatakan efektif bila perlakuan dengan larutan dapar mengakibatka tingkat kematian
$>90 \%$ (Prijono dalam Makal dan Deflly, 2011: 18).

\section{PEMBAHASAN}

Berdasarkan hasil perhitungan (Gambar 2. Diagram tentang mortalitas) tampak jelas perbedaan jumlah mortalitas larva Aedes $s p$ selama pengamatan 24 jam antar perlakuan kontrol, perlakuan dosis larutan daun serai $15 \%$, perlakuan dosis larutan daun serai $20 \%$, perlakuan dosis larutan daun serai $25 \%$, perlakuan dosis larutan daun serai $30 \%$ dan perlakuan dosis larutan daun serai 35\%. Hal ini diketahui dengan menggunakan uji Kruskal-Wallis yang didapatkan hasil $\mathrm{H}_{\text {hit }}$ sebesar 33,79 $(\alpha<0,05)$, maka dapat disimpulkan bahwa ada pengaruh yang bermakna variasi dosis larutan daun serai yaitu (15\%, $20 \%, 25 \%, 30 \%$, dan 35\%) terhadap mortalitas larva Aedes sp.

Mortalitas larva Aedes $s p$ terlihat setelah 2 jam perlakuan. dimana tubuh larva tidak melakukan gerak naik turun kepermukaan serta terlihat tenggelam dan ada juga yang mengapung ketika disentuh dengan jarum ose tidak bergerak. Mortalitas larva Aedes $s p$ ini terlihat pada semua kelompok perlakuan sedangkan pada kelompok kontrol tidak terdapat mortalitas larva Aedes $s p$. Berdasarkan hasil penelitian menunjukkan bahwa mortalitas ratarata terendah terdapat pada konsentrasi $15 \%$ yaitu $38 \% \quad(19$ ekor), dan mortalitas tertinggi terdapat pada dosis larutan 35\% yaitu 98\% (49 ekor). Hal ini dikarenakan pada dosis tersebut dapat membunuh larva Aedes $s p>90 \%$ selama 24 jam. Hal tersebut menunjukkan bahwa semakin tinggi variasi dosis larutan yang diberikan mortalitas larva Aedes sp semakin besar. 
Mengenai hubungan antara dosis larutan daun serai dengan jumla larva yang mati dihubungkan dengan kisaran waktu, dapat dilihat pada Gambar 2. bahwa mortalitas larva terjadi 2 jam pertama setelah perlakuan dan meningkat terus sampai pada 2 jam keduabelas selama 24 jam, seiring dengan meningkatnya variasi dosis larutan daun serai yang diaplikasikan. Dari Gambar 2 dilihat bahwa mortalitas larva tertinggi justru pertama kali terjadi pada perlakuan dengan dosis $20 \%$ dan bukan terjadi pada dosis larutan yang lebih tinggi. Hal ini mungkin berkaitan dengan keragaman genetik dari setiap individu (larva) dalam suatu populasi. Menurut Corbet (dalam Makal dan Deflly, 2011:19) bahwa setiap individu dalam suatu populasi berbeda kecepatan dan cara untuk menetralisir racun yang termakan, maka pantaslah terjadi kematian paling besar pertama kali pada perlakuan dengan konsentrasi larutan yang lebih rendah. Selain itu kerja dari kandungan larutan daun serai yang mengenai tubuh larva belum sepenuhnya memberikan efek yang terlihat jelas. Namun, Secara statistik terlihat perlakuan dengan dosis larutan daun serai $15 \%$ memberikan efek mortalitas yang baik dibandingkan dengan kontrol. Perlakuan masing-masing dosis memberikan pengaruh mortalitas larva Aedes sp. yang berbeda-beda, dapat dilihat bahwa pada dosis $15 \%$, $20 \%, 25 \%, 30 \%$, dan 35\% memiliki jumlah mortalitas yang berbeda-beda namun selisihnya tidak terlalu jauh yaitu antara 5-10 larva Aedes sp. yang mengalami mortalitas. Selisih jumlah larva yang mengalami mortalitas terjadi karena banyaknya selisih dosis, sehingga selisih jumlah mortalitasnya pun tidak terlalu besar yaitu antara 5-10 ekor larva. Hal ini disebabkan karena di dalam setiap dosis larutan daun serai mengandung senyawa toksik yang berbeda-beda sesuai dengan dosisnya, semakin tinggi dosisnya maka kandungan senyawa toksik di dalam larutan tersebut semakin tinggi sehingga menyebakan kematian pada larva Aedes sp. dengan angka mortalitas yang berbeda-beda pula.

Ciri terjadinya mortalitas ditandai dengan larva yang sering muncul kepermukaan dan frekuensinya sangat lama, hal ini mengindikasikan bahwa kebutuhan oksigen yang larut dalam air berkurang sehingga larva sering muncul ke permukaan untuk memenuhi kebutuan oksigen akibatnya terlihat kepala hampir putus karena usaha pencarian udara ke permukaan air. Jika larva kekurangan oksigen, maka larva akan mencoba mengangkat kepalanya kepermukaan air untuk mencari udara sebanyak-banyaknya sehingga kepala larva terulur dan akhirnya menjadi putus. Larva yang mati, usus menjadi hitam, hal ini dikarenakan oleh kandungan larutan daun serai yang masuk kedalam sistem pencernaan yang mengakibatkan rasa panas seperti terbakar. Selain itu, respon terhadap rangsang berkurang yang pada saat disentuh tidak memberikan reaksi. Senyawa sitronella dan geraniol pada tanaman serai. Hal ini serupa dengan penelitian Moehammadi, (2005:04) yang menyatakan bahwa larva yang mati setelah perlakuan mengalami perubahan morfologi di antaranya warna tubuh lebih gelap, ukuran tubuh tampak lebih panjang dan kaku serta kepala yang hampir putus. Indikator larva dikatakan mortal diuraikan oleh Aisiah (2009:112) bahwa Larva akan menunjukan 
perubahan warna tubuhnya menjadi gelap dan gerakannya melambat. Apabila disentuh terdapat gerakan tubuh yang lemah kemudian mati dan ukuran larva lebih panjang dibanding sebelum perlakuan yaitu sebelum perlakuan panjang larva sekitar $5 \mathrm{~mm}$ dan setelah perlakuan menjadi $6 \mathrm{~mm}$.

Hasil penelitian menunjukkan bahwa gejala mortalitas yang terlihat pada larva Aedes $s p$ setelah perlakuan dosis larutan daun serai yakni pada awalnya larva kelihatan gelisah, lama-kelamaan larva menjadi tidak bergerak dan selanjutnya sudah mulai ada larva yang mati. Larva-larva yang mati terlihat pada Gambar 3. sebelum perlakuan dosis dan Gambar 4. setelah perlakuan dosis, pada tubuhnya terjadi perubahan warna menjadi coklat muda dan lamakelamaan diseluruh tubuh menjadi hitam, saluran pencernaan rusak dan kepala hampir putus.

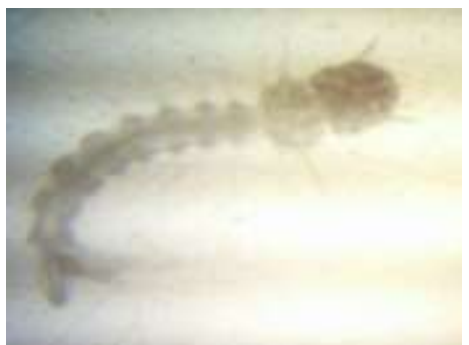

Gambar 3. Larva Aedes sp sebelum perlakuan (sumber: Dok. Pribadi)

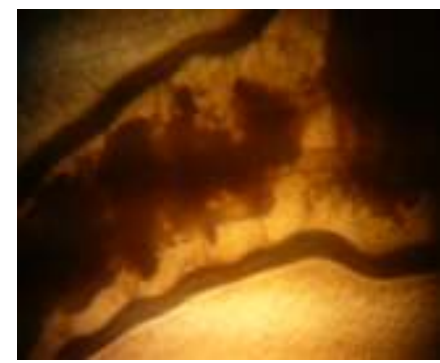

Gambar 4. Larva Aedes sp sesudah perlakuan (sumber: Dok. Pribadi)
Dosis larutan daun serai 35\% merupakan dosis terbaik karena dapat membunuh larva nyamuk Aedes sp. paling banyak dengan mortalitas 98\% selama 24 jam. Setiap kenaikan dosis larutan terlihat bahwa mortalitas larva nyamuk Aedes sp. semakin meningkat, sehingga dengan dosis larutan daun serai $35 \%$ adalah dosis yang tepat terhadap mortalitas larva Aedes sp. Terjadinya kematian larva Aedes $s p$ pada berbagai dosis larutan disebabkan oleh banyaknya senyawa aktif yang kontak langsung dengan larva Aedes sp pada media. Semakin tinggi dosis larutan maka senyawa aktif yang diterima larva Aedes $s p$ juga semakin banyak pula. Senyawa aktif yang terkandung dalam larutan daun serai yaitu sitronellal, geraniol, sitroneol, nerol, dan farnesol yang terdapat di dalam jaringan tanaman serai. Menurut Makal dan Deflly (2011:18) dalam penelitiannya, menyimpulkan bahwa presentase mortalitas larva $C$. binotalis meningkat seiring dengan meningkatnya konsentrasi larutan batang serai yang diaplikasikan. Konsentrasi larutan batang serai 80 $\mathrm{gr} / 50 \mathrm{ml}$ dapat digunakan sebagai insektisida botanis untuk mengendalikan hama $C$. Binotalis, karena pada konsentrasi ini dapat mengakibatkan kematian sebesar 95\% dari total populasi serangga uji.

Kematian larva Aedes sp yakin hanya disebabkan oleh kandungan larutan daun serai yaitu sitronella dan geraniol. Sitronella dapat digunakan untuk insektisida/pestisida nabati. Mekanisme ketika sitronella masuk kedalam tubuh larva yaitu melalui kulit luarnya yang akan menimbulkan reaksi kimia, sehingga menyebabkan desikasi atau kehilangan cairan terus menerus 
yang ada di dalam tubuhnya, mengganggu sistem pernapasan, sistem pencernaan bahkan menyebabkan mortalitas pada larva Aedes sp tersebut.

Serai menurut Narumi, dkk (2012:06) mempunyai kadungan zat aktif berupa sitronella, geraniol, dan flavonoid. Zat sitronella ini mempunyai sifat racun kontak. Sebagai racun kontak, ia dapat menyebabkan kematian akibat kehilangan cairan secara terus menerus sehingga tubuh nyamuk kekurngan cairan. Geraniol adalah adalah senyawa yang dapat menghambat enzim kolin esterase sehingga merangsang saraf motorik secara menerus yang berakibat kejang serta kelelahan. Serta bahan aktif yang ketiga adalah flavonoid yang bekeja sebagai racun pernapasan yang masuk kedalam mulut kemudian melalui sistem pernapasan dan menimbulkan kelayuan pada saraf (Pinardi dkk, 2010:86).

Hal ini juga diperkuat oleh penelitian Hardi dan Riko (2007:06) yang menyatakan bahwa serai tidak membunuh rayap secara cepat, tetapi berpengaruh mengurangi nafsu makan, pertumbuhan, daya reproduksi, proses ganti kulit, hambatan menjadi serangga dewasa, sebagai pemandul, serta mudah diabsorbsi oleh tanaman. Aplikasi insektisida larutan serai dengan konsentrasi $1 \%$ dan $2 \%$ dapat menekan instensitas serangan rayap tanah Macrotermes gilvus, serta pada konsentrasi $2 \%$ memberikan hasil yang paling efektif dalam menurunkan instensitas serangan rayap tanah. Pada awalnya minyak serai tidak mempengaruhi jumlah makanan yang dikonsumsi, namun setelah tubuh merasa terganggu, biasanya serangga melakukan respons kompensasi dengan cara mengurangi jumlah pakan yang dikonsumsinya. Penurunan tersebut terjadi karena larva menetralisir racun yang ada. Selain bersifak toksik terhadap serangga, senyawa sitronella yang terdapat pada tanaman serai juga memiliki sifat sebagai anti makan (Hasyim dkk, 2010:381).

Berdasarkan mortalitas larva Aedes sp tersebut menunjukkan bahwa kandungan senyawa yang terdapat dalam daun serai efektif dalam mortalitas larva Aedes sp. Hal ini menunjukan bahwa hasil penelitian sesuai dengan teori dan para peneliti sebelumnya yang telah menjadi rujukan, bahwa kandungan daun serai dapat digunakan sebagai insektisida nabati.

Berdasarkan fakta yang diperoleh dari hasil penelitian tersebut maka dapat diintegrasikan dapat bentuk konsep sebagai berikut:

1. Hasil penelitian dapat digunakan sebagai bahan rancangan atau sumber belajar siswa SMP kelas VIII semseter ganjil, pada standar kompetensi Memahami Pertumbuhan dan Perkembangan Mahluk Hidup dengan kompetensi dasar Menganalisis pentingnya pertumbuhan dan perkembangan pada mahluk hidup, pada sub materi metamorfosis pada hewan.

2. Pemanfaatan hasil penelitian dalam pembelajaran berupa rancangan sumber belajar dalam bentuk Lembar penuntun praktikum siswa.

3. Pertumbuhan dan perkembangan larva nyamuk Aedes sp sampai menjadi nyamuk dewasa melalui beberapa tahap, dengan demikian tahap perkembangan nyamuk Aedes sp dapat diamati secara 
langsung dari hasil penelitian yang sudah dilakukan.

4. Umur larva merupakan faktor yang sangat berpengaruh terhadap daya tahan larva terhadap insektisida oleh karena itu pemilihan larva merupakan hal yang sangat penting dalam penelitian. Kisaran larva yang digunakan dalam penelitian adalah pada instar II akhir/3 awal yaitu pada rentan usis 4-5 hari setelah penetasan. Karena pada usia ini organ tubuh larva sudah terbentuk dengan baik.

5. Daun serai dapat menghambat pertumbuhan larva Aedes sp sehingga tidak dapat berubah menjadi nyamuk dewasa bahkan larva mengalami kematian, dengan demikian larutan daun serai dapat digunakan untuk membasmi penyebaran nyamuk Aedes sp sebagai vektor penyakit DBD.

6. Daun serai dapat digunakan sebagai insektisida nabati yang ramah lingkungan karaena bersifat biodegradable, mudah terurai oleh bakteri dan jamur sehingga tidak mencemari lingkungan sekitar serta membuat ekosistem tetap terjaga.

Biologi pada hakikatnya terdiri dari produk dan proses. Pembelajaran biologi baik di sekolah tidak cukup hanya teori saja, tetapi memerlukan sebuah percobaan atau praktikum. Disamping itu, pendidikan saat ini beracuan pada kurikulum 2013, akan tetapi kurikulum ini masih belum terealisasi dengan baik. Sehingga dalam pembelajaran masih banyak sekolah-sekolah yang menggunakan kurikulum KTSP.

Sumber belajar adalah segala sesuatu yang dapat memberikan kemudahan kepada siswa dalam memperoleh sejumlah informasi, pengetahuan, pengalaman, dan keterampilan. Sumber belajar dipilih dan digunakan apabila sesuai dan menunjang tercapainya tujuan, karena tidak setiap sumber belajar tepat untuk digunakan. Sumber belajar biologi harus berkaitan dengan materi yanga ada di SMP, paling tidak sumber tersebut tidak terlalu jauh dengan materi minimal ada beberapa yang dibahas meskipun tidak banyak, akan tetapi sudah memberikan wawasan dan pengalaman belajar untuk siswa. Di SMP mata pelajaran Biologi masuk dalam mata pelajaran IPA terpadu, sehingga menjadi satu dengan mata pelajaran lain, seperti Fisika, dan Kimia. Melalui pembelajaran IPA terpadu, siswa dapat memperoleh pengalaman langsung, menanamkan pentingnya pengamatan empiris dalam menguji pernyataan ilmiah, melatih berpikir kuantitatif sehingga dapat menambah kekuatan untuk menerima, menyimpan, dan menerapkan konsep yang telah dipelajarinya. Dengan demikian, siswa terlatih untuk dapat menemukan sendiri berbagai konsep yang dipelajari secara menyeluruh (holistik), bermakna, autentik dan aktif.

Dengan digunakannya sumber belajar berupa hasil penelitian bahwa dalam tahap perkembangan sampai menjadi nyamuk dewasa, telur larva mengalami beberapa tahapan, maka konsep ini dapat diterapkan dalam sub metamorfosis pada hewan, hal ini dapat memberikan keleluasaan bagi siswa dalam upaya menggali informasi dan pengetahuan yang berhubungan dengan materi yang dipelajari tersebut. Dengan demikian kemampuan siswa dapat dikembangkan secara optimal sehingga proses belajar mengajar 
lebih aktif dan kreatif, sehingga pembelajaran dapat berhasil dengan baik dan diperoleh prestasi belajar yang baik pula. Dari hasil penelitian dapat digunakan sebagai bahan dalam pembuatan rancangan sumber belajar dalam bentuk lembar penuntun praktikum siswa yang dalam penerapannya dalam kegiatan praktikum pada SMP Kelas VIII Semester ganjil materi pertumbuhan dan perkembangan dan sub materi metamorfosis pada hewan

\section{KESIMPULAN}

Berdasarkan hasil penelitian dapat disimpulkan bahwa:

1. Ada pengaruh variasi dosis larutan daun serai terhadap mortalitas larva Aedes $s p$ dengan nilai koefisien $\mathrm{H}=$ 33,79 maka nilai chi-square 19,67 pada taraf nyata $\alpha=$ 0,05 .

2. Pada larutan daun serai dosis $35 \%$ merupakan dosis terbaik yang memiliki pengaruh paling besar terhadap mortalitas larva Aedes sp.

3. Hasil penelitian dapat berpotensi sebagai sumber belajar biologi kelas VIII semester ganjil pada sub materi metamorfosis pada hewan.

\section{SARAN}

1. Untuk masyarakat:

a. Diharapkan agar dapat menggunakan bahan pestisida/insektisida yang ramah lingkungan dalam membasmi larva Aedes $s p$, seperti daun serai yang sudah tua dan diproduksi.

b. Untuk air yang telah terdapat larutan sebaiknya tidak digunakan untuk minum, tetapi digunakan untuk air cuci.

2. Untuk tenaga pendidik, khususnya Guru SMP hasil penelitian dapat dijadikan sebagai sumber bahan ajar biologi SMP Kelas VIII Semester ganjil berupa lembar penuntun praktikum pada sub pokok bahasan metamorfosis pada hewan.

3. Untuk peneliti selanjutnya:

a. Pada pemilihan daun serai sebaiknya daun serai yang sudah tua, dengan ciri berwarna hijau keunguan dan agak kering. Sebab ketuaan daun serai akan mempengaruhi tingkat efektifitas dari senyawa sitronella dan geraniol yang terdapat di dalam daun serai

b. Dalam aplikasi menggunakan dosis larutan 35\% karena pada dosis ini adalah dosis yang telah menunjukkan mortalitas $>90 \%$.

c. Sebaiknya meneliti lebih lanjut untuk membasmi nyamuk Culex, Anopheles dengan menggunakan larutan daun serai, maupun dengan tanaman lain.

\section{DAFTAR RUJUKAN}

Adiseputra, I Gede Karang. 2009. Tanaman Serai Untuk Membunuh Nyamuk. IPTEKMA. Vol 1.No.1. ISSN: 2086-1354.

Aisiah, Siti. 2009. Efektivitas Ekstrak Eranol Daun Rambutan (Nephelium lappaceum L) Terhadap Kematian Larva Nyamuk Aedes aegypti Instar III. Jurnal 
Kesehatan. Vol. 2. NO. 2. Hal. 103-114. ISSN. 1979-7621.

Arswendiyumna, Regalado. Perry Burhan dan Yulfi Zetra. 2011. Minyak Atsiri Dari Daun Dan Batang Tanaman Dua Spesies Genus Cymbopogon, Famili Gramineae Sebagai In sektisida Alami dan Antibakteri. Skripsi tidak diterbitkan. Surabaya: Fakultas Matematika Dan Ilmu Pengetahuan Alam.

Hanafiah, Kemas Ali. 2011. Rancangan Percobaan Teori dan Aplikasi. Jakarta: PT Grafindo Persada.

Hardi, Teguh dan Riko Kurniawan. 2007. Pengendalian Rayap Tanah pada Tanaman Kayu Putih dengan Ekstrak Sereh Wangi. Balai Besar Penelitian Bioteknologi dan Pemuliaan Tanaman Hutan. Fakultas Kehutanan Universitas Nusa Bangsa.

Hasyim, A. dkk. 2010. Efikasi dan

Persistensi Minyak Serai Sebagai Biopestisida terhadap Helicoverpa armigera Hubn. (Lepidoptera: Noctuidea). Jurnal Hortikultura. Vol 20. No. 4. Hal. 377-386.

Kardinan, Agus. 2003. Pestisida Nabati Ramuan dan Aplikasinya. Jakarta: Penebar Swadaya.

Makal, Henny V.G. dan Deflly A.S. Turang. 2011. Pemanfaatan Ekstrak Kasar Batang Serai untuk Pengendalian Larva Crosidolomia binotalis Zell. pada Tanaman Kubis. Eugenia. Vol. 17 No.1.

Moehammadi, Noer. 2005. Potensi Biolarvasida Ekstrak Herba Ageratum conyzoides Linn. dan Daun Saccopetalum horsfieldii Benn terhadap larva Nyamuk
Aedes aegypti L. Jurnal Berk. Panel Hayati. No. 10. Hal 1-4.

Naria, Evi. 2005. Insektisida Nabati Untuk Rumah Tangga. Info Kesehatan Masyarakat. 28-32.

Narumi, Hayakawa. 2012. Uji Potensi Larutan Daun Serai (Cymbopogon nardus) Sebagai Insektisida Nyamuk Culex sp Dengan Metode Elektrik. Tugas Akhir: Fakultas Kedokteran Universitas Brawijaya.

Pinardi, Tuhu, Heri Koesmantoro dan Moch. Yulianto. 2010. Pengaruh Larutan Serai Wangi dan Daun Tembelekan Terhadap Daya Tolak Gigitan Nyamuk Aedes aegypti. Jurnal Penelitian Kesehatan Suara Forikes. Vol 1. No 1. ISSN:2086-3098.

Ulfah, Yusrina, Abdul Gafur dan Eny Dwi Pujawati. 2009. Penetasan Telur dan Mortalitas Pupa Nyamuk Aedes aegypti Pada Perbedaan Konsentrasi Air Rebusan Serai (Andropogon nardus L). Bioscientiae. Vol 6. No. 2. 3748. 